\title{
Histopathological changes in the gills of some fishes inhabiting polluted Singhiya river, Biratnagar, Nepal
}

\author{
Bharat Raj Subba ${ }^{1}$ and Bikash Khanal ${ }^{2} *$ \\ ${ }^{1}$ Department of zoology, Post Graduate campus, T.U., Biratnagar, Nepal \\ ${ }^{2}$ Arniko HSS, Biratnagar, Nepal*E-mail: bikash32662@gmail.com
}

\begin{abstract}
Histopathological effects on the gills of a few fish species of polluted Singhiya river, Biratnagar sub-metropolis was made. The gills sections of Oxygaster bacaila, Neomacheilus botia,, Glossogobius giuris, Puntius sophore, Barillius barana, Channa gachua and Silorhynchus sucatio were found much deformed. Lesions, abnormal growth of taste buds and inter-lamellar space, fusion at the tips of primary as well as secondary lamellae, shifting of epithelial layer, deformation of gill head and that of outer margin, tilted secondary lamellae were found common.
\end{abstract}

Key words: Histopathology, gills, fishes, Singhiya river

\section{Introduction}

Biratnagar sub-metropolis (Lat. $26^{\circ} 20^{\prime} \mathrm{N}$ and Long. $87^{\circ} 16^{\prime} \mathrm{E}$; Elevation $72 \mathrm{msl}$ ) is the second largest and polluted town of Nepal next to the capital city Kathmandu. The whole length of the sub- metropolis forms a polluted corridor as there are several industries situated on both sides of the highway. Biratnagar is teeming with human population. Every year thousands of buildings and huts are constructed without town planning. The management of wastes and sewage is unscientific as such the adjoining river is being polluted. For example, the aquatic ecosystem of Singhiya river is in pathetic condition. A few species of fishes are struggling here to exist, herpeto-fauna is being rare and plankton condition is worse.

Some works on the toxic effects of insecticides and other pollutants on respiratoray organs (gills), liver and kidney of fishes include Skidmore (1964), Eisler (1970), Mirtovic (1970), Eller (1971), Solbe et al. (1975), Shukla (1978), Bhakthavathsalam (1980), Goel and Garg (1980), Pant et al. (1980), Kling (1981), Ramalingam et al. (1981), Saha and Konar (1983), Rashatwar and llyas (1984), Saha and Konar (1986), Bhakthavathsalam et al. (1987), Mane et al. (1987), Saha and Konar (1987), Arun et al. (1998). Similarly, Skidmore (1964), Munshi and singh (1971), Singh and Sahni (1984), Roy and Munshi (1991) and Nath and Jaipuriya (1996) have given account of changes in the gills of fish due to toxicity of zinc, malathion and other insecticides. Du Preez et al. (1997) investigated bio-accumulation of selected metals in African sharp tooth catfish Clarias gariepiums from the lower Olifants river, Mpumalanga, South Africa. He found the metals deposited in muscles liver, even in the kidney of the fish.

\section{Materials and Methods}

Fishes were caught from Singhiya river with the help of local fishermen. Two local fishermen were hired to catch fish for eight hours/ month during March-April, 2005. Fishes were caught randomly at a stretch of $3 \mathrm{~km}$ of the river within Biratnagar. The live fishes 
caught were washed with clean water and immediately anaesthetized with Ms222 and dissected out so as to expose their gills. The external condition of the body and the gills were examined closely to know whether there were any changes.

Gills of Puntius sophore, Oxygaster bacaila, Nemacheilus botia, Glossogobius giuris , Barillus barana, Channa gachua and Silorhynchus sucatio were taken out carefully one by one and washed with distilled water so as to remove mud particles, mucus etc. and then they were fixed in freshly prepared Bouin's fixative. The four primary gill lamellae were separated before putting them in fixative. The materials were fixed in fixative for $22 \mathrm{~h}$. The gills of each fish species were kept in separate vials with proper labeling. Bouin's fluid of each vial was changed at an interval of $6 \mathrm{~h}$. When proper fixation of gills was over, they were transferred to $70 \%$ alcohol and washed several times, then cut into small suitable pieces for microtome. After that they were transferred to decalcifying agent $(95 \mathrm{ml} 70 \%$ alcohol $+5 \mathrm{ml}$ conc. HNO3) and kept for $96 \mathrm{~h}$. They were then washed with $70 \%$ alcohol several times and dehydrated following alcohol series. The dehydrated pieces of the gills were passed to melted paraffin wax for infiltration and then paraffin blocks were prepared. The gills were cut into sections at 5 to $6 \mu \mathrm{m}$. The sections were stained using haematoxyline and counter stain eosin in alcoholic series. Then permanent slides were prepared. The histological slides were observed minutely under the light microscope then their microphotographs were taken with the help of trinocular microscope in Botany Laboratory of Mahendra Morang Adarsh Multiple Campus, Biratnagar.

\section{Results}

Observations of the sections of gills under the light microscope as well as in micro photographs made it clear that there have been drastic changes in water quality of the river which has affected gills of fishes.

The drainages which carry effluents and degradable and non-degradable waste materials to be disposed in the river have been found to have direct connection with river. The water of Singhiya River was found to be contaminated and polluted. The colour and smell of water indicated that the water was not suitable for any life. However cattle grazers were seen taking bath with wallowing buffalos throughout the length of river. Washing clothes and utensils and taking bath were common sights in the river sides. Both sides of the river were found full of human excreta and non-degradable plastic bags, broken glasses etc.

So far the study of fishes is concerned, no fish species studied was found free from pathological problems in their gills. The histology of gills of Oxygaster bacaila, Puntius sophore, Noemacheilus botia, Silorhynchus sucatio, Barillus barana, Channa gachua showed their respiratory organs (gills) were found in bad condition.

Gills of fishes were found to have histological lesions. The secondary lamellae which are the main sites of gas exchange in the gill breathing fishes were seen swollen and abnormal. The tips of primary as well as secondary lamellae were seen club-shaped by lamellar fusion (Fig. 3 ), and shortening of the length of secondary lamellae was common. Large number of mucus cells and taste buds in the gill heads and gill rakers (Fig. 6) indicated that fishes were suffering from polluted water in Singhiya river. The toxicants might be either from industries or from agricultural farms. 


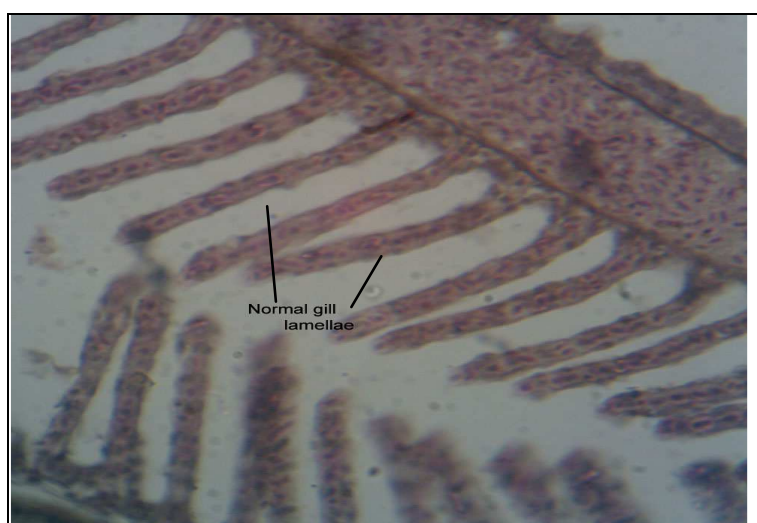

Figure 1. Normal gill filaments from unpolluted water $(\times 10)$

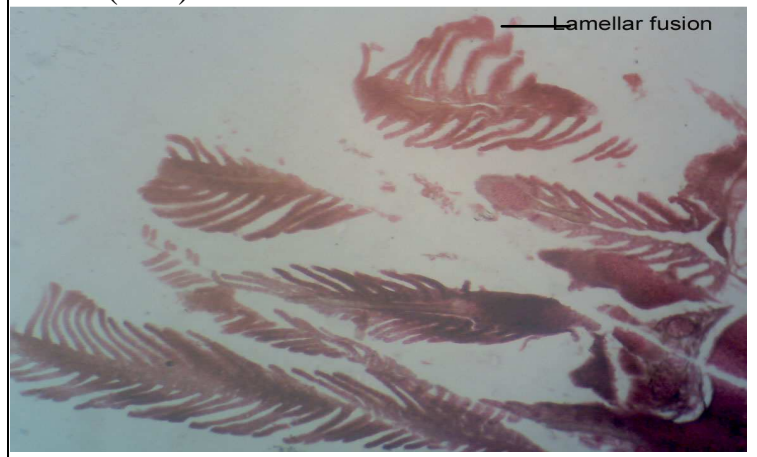

Figure 3. Lamellar fufion of Puntitus sophore

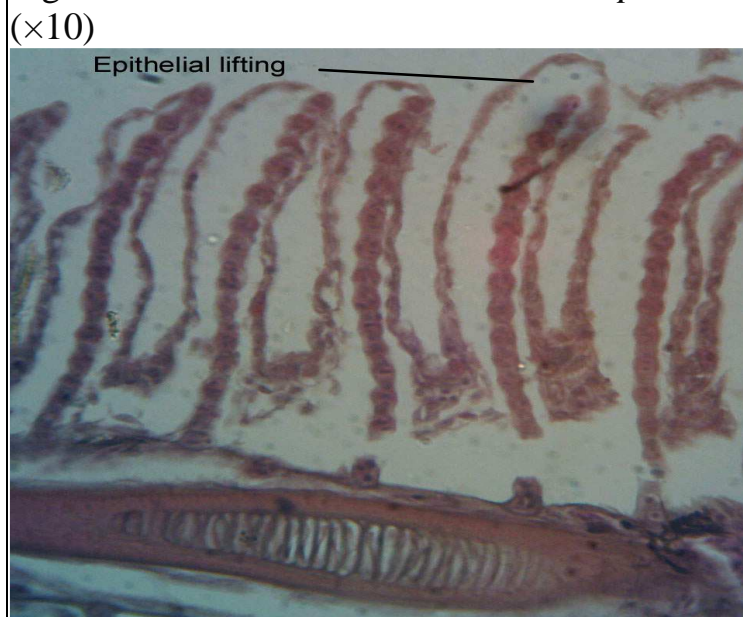

Figure 5. Shifted epithelium of gill lamellae in Puntius sophore $(\times 10)$

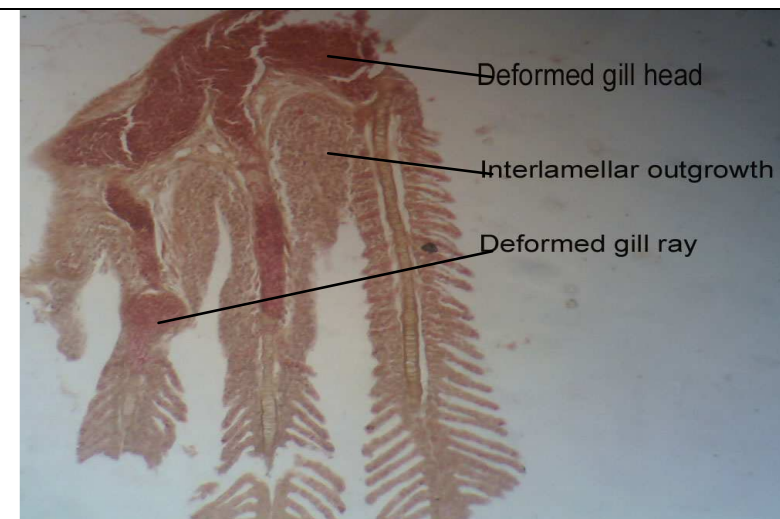

Figure 2. Deformed muscles at the base of gill lamella of Nemacheilus botia $(\times 10)$

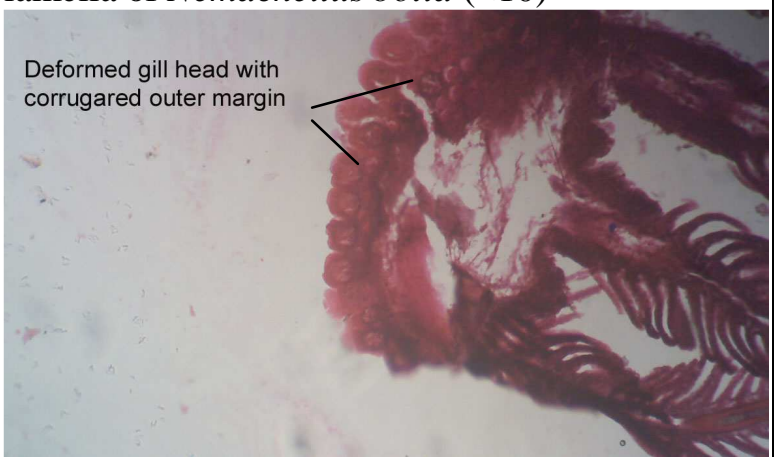

Figure 4. Deformed gill head with corrugated outer margin in Oxygaster bacaila $(\times 10)$

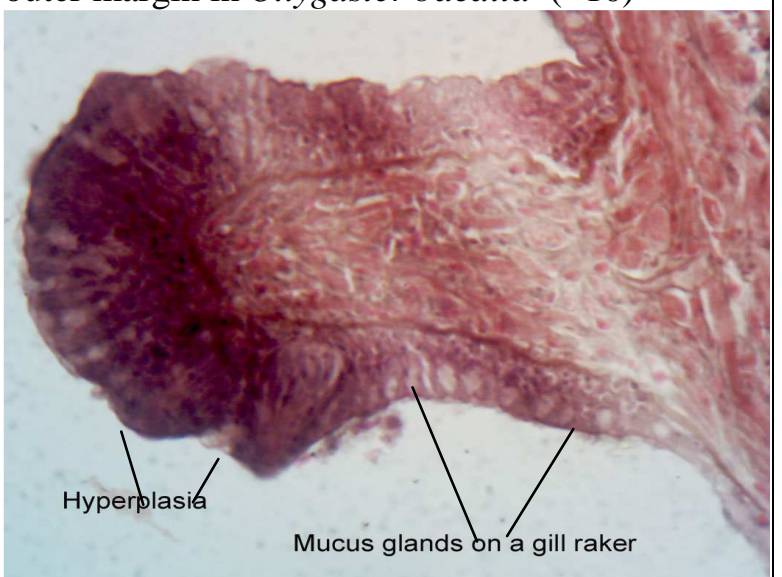

Figure 6. hyperplasia on the gill raker of Glossogobius giuris $(\times 45)$

Plate 1. Microphotography of gills of different fishes.

\section{Discussion}

The findings of this work indicate that polluted water of the river has detrimental effects on fish fauna. Though there is no available list of fishes of Singhiya river in printed form but knowledge of fisherman whose occupation is confined to catching fish can be taken as living document. The Singhiya river was inhabited by sixty species of fishers in the summer and at least thirty species throughout the year according to fishermen. Due to pollution only 15 
species of fishes were found in the river during March to April in 2005. Among 15 fish species, Barillius barana and Puntius species were found to be dominating. A single representative of Oxygaster bacaila, Mystus tengra, Channa gachua, Chagunius chagunio, Silorhynchus sucatio, Cirrhinus reba and two representatives from other species such as Glossogobius giuris, Nemacheilus botia, Rosbora daniconius and Danio devario were found in the present collection.

From the number of each fish species caught, it can be concluded that most of the fish species are going to disappear from Singhiya river because of increasing population in the river. The existing species are also facing several histological changes in their gills due to the effect of pollutants such as insecticides. Perhaps, their kidneys, pancreas, brain, testes, ovaries and alimentary canal are equally affected. The worst condition was observed in the gills of Nemacheilus botia which indicated that fish species would not be able to exist in this polluted water. Deformed gill head, gill rakers and interlamellar hyperplasia (Fig. 2), lamellar fusion (Fig. 3), corrugated gill heads (Fig. 4), epithelial lifting (Fig. 5) and increased number of mucus glands and taste buds in the gill rakers and gill head (Fig. 6) were some of the abnormalities observed under the light microscope. The findings of present work corroborate with the findings of several researchers (Eisler, 1970; Eller, 1971; Goel \& Garg, 1980; Singh \& Sahni, 1984; Roy \& Munshi, 1991; Fernandes \& Mazon, 2003; Marina \& Claudia, 2007; Ileana et al., 2012).

The finding of the investigation made on bio- accumulation in tissues, muscles, gills and kidneys, liver and gonads and bile of the African catfish Clarias gariepinus from the lower Olifants river, south Africa by Du Preez et al. (1997) states that accumulation of metal in high concentration was in gills, liver or gonadial tissue. The researchers had made comparative study of bio- accumulation on fishes living in two different rivers. They had obtained different results. Similar findings in the gills structure have been found in the preset work.

\section{Acknowledgement}

First author (BR Subba) is thankful to Biratnagar Submetropolis for financial assistance.

\section{References}

Arun, K., R. Srivastava, N.D. Sinha \& S.J. Srivastava. 1998. Histopathological changes in a catfish Heteropneustes fossilis following exposure to malachite green. Proc. Nat. Acad. Sci. India 68(B): 1.

Bhakthavathsalam, R., N. Murugaboopathy and P. Karan. 1987. Effects of carbofuran on certain tissues of the fish Lepidocephalichthys thermalis Environ. Ecol. 5(2): 216- 219.

Du Preez, H.H., M. Van der Merwe, \& J.H. Van Vuren. 1997. Bio accumulation of selected metals in African sharptooth catfish Clarias gariepinus from the lower Olifants River, Mpumalanga, South Africa. Koedoe 40(1): 77-90.

Eisler, R. 1970. Factors affecting pesticide induced toxicity in an estuarine fish. Wildl., Tech. Paper 45, WS Bur. Sport fish. Wildl., Washington, USA.

Eller, L.L. 1971. Histopathological lesions in cutthroat trout exposed to the insecticide, endrin. Am. J. Pathol. 64: 321-355. 
Fernandes, M.N. \& A.F. Mazon. 2003. Environmental pollution and fish gill morphology. In: Fish adaptations (Eds. A.L. Val \& B.G. Kapoor). Enfield, Science Publishers. pp. 203231.

Goel, K.A. \& V. Garg. 1980. Histopathological changes produced in the liver and kidney of Channa punctatus after chronic exposure to 2, 3, 4 triamino azobenzene. Bull Environ. contam. Toxicol. 25: 330-334.

Ileana, C., T.J. Cazenave, C. Bacchetta, Maria de los, A. Bistoni. 2012. Histopathological changes in the gills and liver of Prochilodus lineatus from the Salado river basin(santa Fe, Argentina). Fish Pathology and Biochemistry 38(3): 693-702.

Kling, D. 1981. Total atresia of the ovaries of Tilapia lencastica (Cichlidae) after intoxication with the insecticide lebaycid. Berkhauser Verlag, Basel (Schweiz).

Mane, U.H. \& S.R. Akarte. 1987. Toxicity of Labaycid to three species of freshwater Lamellibranch Molluscs in different seasons. Environ. Ecol. 5(2): 342-351.

Marina, M.P. Camargo \& B.R. Martinez Claudia. 2007. Histopathology of gills, kidney and liver of a Neotropical fish caged in an urban stream. Neotropical Ichthyology 5(3): 327336.

Munshi, J.S. Datta \& R.K. Singh. 1971. Investigation on the effects of insecticides and other chemical substances on the respiratory epithelium of the predatory and weed fishes. Ind. J. Zool. 12(2): 127-134.

Nath, R. \& A.R.K. Jaipuryar. 1996. Acute toxicity of lindane on the Hematological parameters in the Heteropneustes fossilis (Blotch). J. Fresh Water Biol. 8(2): 105-107.

Pant, S.C., S. Kumar \& S.S. Khanna 1980. Toxicity of copper sulfate and zinc sulfate to a fresh water teleost Puntius conchonius (Ham.) in hard water comps. Physiol. Ecol. 5: 146-149.

Ramalingam, R. \& Y. Srivastava Reddy. 1981. Acute histopathological effects of Indane (benzene hexachloride) on the liver of Colisa lalia. Curr. Sci. 50: 578-580.

Rashatwar, S.S. \& R. Ilyas. 1984. Effects of phosphomidon in a freshwater teleost fish, Nemaciclins denisonil (Day): Histopathological biochemical studies. J. Environ Biol. 5: $1-8$.

Roy, P.K. \& J.S.D. Munshi. 1991. Malathion induced structural and morphometric changes of gills of a freshwater major carp, Cirrhinus mrigala (Ham.). J. Environ. Biol. 12(1): 879887.

Saha, M.K. \& S.K. Konar. 1983. Acute toxicity of some petroleum pollutants to plankton and fish. Environ. Ecol. 1: 117-119.

Saha, M.K. \& S.K. Konar. 1986. Chronic sub lethal effects of crude petroleum on fish. Environ. Ecol. 4: 494-499.

Saha, M.K. \& S.K. Konar. 1987. Chronic sub lethal effects of mixture of crude petroleum and emulsifier on fish. Environ. Ecol. 5(2): 223-229.

Shukla, G.R. 1978. Acute toxicity of zinc sulfate to four fresh water teleost fishes. Symp. Environ. Biol., Muzaffarnagar, India.

Singh, S. \& S. Sahni. 1984. Histopathological changes in the gills of Rasbora daniconius induced by BHC. J. Environ. Biol. 5(2): 65-69.

Skidmore, J.F. 1964. Toxicity of zinc compounds to aquatic animals with special reference to fish. Q. Rev. Biol. 39: 227-248.

Solbe, J.F., L.G. De \& A. Flook. 1975. Studies on toxicity of zinc sulfate and cadmium sulfate to stone loach Noemacheilus barbatulus (L.) in hard water. J. Fish. Biol. 7: 631-637. 